\title{
Modification of beech veneers with $N$-methylol-melamine compounds for the production of plywood
}

\author{
Hien Mai Trinh $\cdot$ Holger Militz $\cdot$ Carsten Mai
}

Received: 10 August 2010 / Published online: 25 August 2011

(C) The Author(s) 2011. This article is published with open access at Springerlink.com

\begin{abstract}
Rotary cut beech (Fagus sylvatica L.) veneers were treated with two formulations based on $N$-methylolmelamine (NMM): (1) NMM solution (NMM-1, 10\% solid content), (2) fatty acid modified NMM dispersions containing paraffin (with an aluminium salt as catalyst, mNMM-2, $5 \%$ solid content). Five treated veneers were bonded with phenol formaldehyde (PF) adhesive to produce plywood in two different processes.

The plywood treated with NMM-1 displayed increased shear strength in comparison to the controls, whereas the treatments with mNMM-2 diminished the shear strength of the plywood to different extents. Treatment with NMM-1 also enhanced other mechanical properties of the plywood as compared to water-treated control plywood such as Brinell hardness, modulus of elasticity and bending strength. The plywood treated with mNMM-2 showed only slight changes of these mechanical properties compared to the control plywood.

The plywood specimens were subjected to cyclic water submersion and oven-drying. The treatment with mNMM-2 caused greater reduction in water uptake and thickness swelling than NMM-1; the degree of delamination depended on the process. The plywood treated with NMM-1 exhibited lower equilibrium moisture content than that treated with mNMM-2. The formaldehyde emission of NMM-1-treated plywood was much higher than that of the control and the mNMM-2-treated plywood.
\end{abstract}

H.M. Trinh · H. Militz · C. Mai $(\bowtie)$

Wood Biology and Wood Products, Burckhardt-Institute, Georg August University of Göttingen, Büsgenweg 4, 37077 Göttingen, Germany

e-mail: cmai@gwdg.de

\section{Modifizierung von Buchenfurnieren mit $N$-Methylol-Melamin-Verbindungen zur Herstellung von Sperrholz}

Zusammenfassung Buchenschälfurniere (Fagus sylvatica L.) wurden mit zwei auf $N$-Methylol-Melamin (NMM) basierenden Formulierungen behandelt: 1. NMM-Lösung (NMM-1, 10\% Feststoffgehalt), 2. Fettsäure-modifizierter NMM-Dispersion mit Paraffin (mit einem Aluminiumsalz als Katalysator, mNMM-2, 5\% Feststoffgehalt). Fünf Furniere wurden mit Phenol-Formaldehyd (PF)-Harz nach zwei unterschiedlichen Prozessen zu Sperrholz verklebt.

Das mit NMM-1 behandelte Sperrholz wies im Vergleich zu den Kontrollen eine erhöhte Scherfestigkeit auf, während die Behandlung mit mNMM-2 die Scherfestigkeit des Sperrholzes in unterschiedlichem Ausmaß reduzierte. Die Behandlung mit NMM-1 erhöhte außerdem andere mechanische Eigenschaften wie die Brinellhärte, den Elastizitätsmodul und die Biegefestigkeit. Das mit mNMM-2 behandelte Sperrholz zeigte im Vergleich zum Kontrollsperrholz nur leichte Veränderungen der genannten mechanischen Eigenschaften.

Die Sperrholzproben wurden einem zyklischen Test bestehend aus Tauchen in Wasser und Ofentrocknung unterzogen. Die Behandlung mit mNMM-2 verursachte eine stärkere Abnahme der Wasseraufnahme und der Dickenquellung als NMM-1; der Grad der Delaminierung war dabei vom Prozess abhängig. Das mit NMM-1 behandelte Sperrholz zeigte eine niedrigere Gleichgewichtsfeuchte als das mit mNMM-2 behandelte. Die Formaldehydabgabe von NMM1-behandeltem Sperrholz war sehr viel höher als die der Kontrolle und des mNMM-2-behandelten Sperrholzes. 


\section{Introduction}

Many efforts have been undertaken in order to improve the dimensional stability of wood as well as its decay and weathering resistance, and thereby to prolong the service life in outdoor application through chemical modification (Hill 2006). Solid wood treated with melamine-based compounds exhibited remarkable improvements, such as enhanced water repellence and dimensional stability (Inoue et al. 1993; Lukowsky 2002; Nguyen et al. 2007; Pittman et al. 1994) as well as increased hardness, modulus of elasticity (MOE) and bending strength (Deka and Saikia 2000; Gindl et al. 2004; Inoue et al. 1993). In addition, $N$-methylol-melamine (NMM)-treated wood indicated the potential to increase the resistance against wood destroying fungi (Lukowsky et al. 1999; Rapp and Peek 1996) and deterioration caused by natural weathering (Rapp and Peek 1999).

Dimensional stabilisation and sorption behavior were shown to depend on the molar mass of the NMM molecules and on the related formaldehyde content in the formulation. This was attributed to the penetration of NMM and bulking of the cell wall matrix (Lukowsky 2002). Formaldehyde emissions during and after curing increased with increasing molar ratio formaldehyde to melamine $(\mathrm{F} / \mathrm{M})$ in the resins (Lukowsky 2002). Curing temperatures in the range between $120-140^{\circ} \mathrm{C}$ for a period of several hours were required to reduce the formaldehyde emission of solid wood specimens treated with $15 \%$ NMM solutions to values ranging from 1.2-3.7 $\mathrm{g} \mathrm{kg}^{-1}$ (using a modified flask-method according to EN 717-3), the higher value corresponding approximately with the so-called E1 class limit. Addition of pure urea to the NMM formulation was shown to reduce formaldehyde emissions from wood during service life (Lukowsky et al. 1998).

Fatty acid modified NMM has been previously applied to treat solid wood (Nguyen et al. 2007). The treatment considerably reduced the water up-take in a submersion test but induced only a minor degree in dimensional stabilisation and reduction in vapour sorption at $10-15 \%$ WPG. Outside exposure over 1 year revealed less cracking and blue stain as compared to untreated wood. In addition, the decay resistance against basidiomycetes was highly increased and the colonisation by the blue stain fungus Aureobasidium pullulans significantly reduced due to the treatment.

European beech is one of the most important wood species used in the veneer industry in Germany. It is easily treatable, but its low durability limits the area of application. Modification of veneers for the production of plywood might improve many properties such as dimensional stability, resistance to biodegradation and weathering, and strength properties of the plywood. Like with other wood-based panels, the strength and other properties of plywood are based on the properties of the ve- neers and on the adhesive bonds formed between the veneers. Hence, improving the veneer properties and bonding quality plays an important role in the development of higher performing materials (Rohumaa et al. 2007). For conventional products, adhesive properties, quality of veneers, and process parameters are the main factors affecting the performance of plywood (Dunky 2003; Scheikl and Walinder 2002). Several attempts have been undertaken to improve the properties of plywood by chemical modification of the veneers, e.g., through acetylation (Vick and Rowell 1990) or treatment with 1,3-dimethylol4,5-dihydroxyethyleneurea (DMDHEU) (Dieste et al. 2008, 2009).

The objective of this work was to investigate the influence of veneer modification with two $N$-methylol-melamine compounds using two different processes (with and without curing prior to hot pressing the treated veneers to plywood) on the bonding quality, hardness, as well as the modules of rupture (MOR) and elasticity (MOE) of the plywood. In addition, water repellence, dimensional stability, sorption behavior and formaldehyde emission was assessed. The main purpose of the NMM-treatment was to increase the weathering resistance of plywood used outdoors. The veneers were bonded with a phenolic adhesive, because the $\mathrm{C}-\mathrm{C}$ bonds between the aromatic nuclei and the methylene bridges are resistant to hydrolysis (Dunky 2003).

\section{Materials and methods}

\subsection{Chemicals}

Methylated $N$-methylol-melamine (NMM-1) was Madurit MW 840/75 WA (Ineos Melamines, Frankfurt/Main, Germany). It was supplied as an aqueous stock solution with a solid content of approx. 75\% (determined by evaporation of water at $120^{\circ} \mathrm{C}$ for $1 \mathrm{~h}$ ). The dynamic viscosity of the formulation was $430 \mathrm{mPa}$ s, the density $1,256 \mathrm{~g} \mathrm{ml}^{-1}$ and the pH-value 9.3 (all values at $25^{\circ} \mathrm{C}$ ). NMM-1 is partly methylolated (with residual amino groups of the melamine) and partly methylated; the behavior of NMM-1, hence, is rather hydrophobic, but still with the possibility of hardening.

The fatty acid modified $N$-methylol-melamine formulation containing paraffin (mNMM-2) was Phobotex VFN (Ciba, Basel, Switzerland). It is a white, slightly cationic emulsion with a $\mathrm{pH}$-value of 5.3 and a specific gravity of $0.991 \mathrm{~g} \mathrm{ml}^{-1}$ at $25^{\circ} \mathrm{C}$. Due to the modification with fatty acid and the addition of paraffin the substance shows predominately hydrophobic character. A commercial catalyst solution (Catalyst RB, Ciba, Basel, Switzerland) was used for the curing of Phobotex VFN. Phenol formaldehyde (PF) resin used for the bonding of veneers was Prefere 4976 (Dynea, Erkner, Germany). 


\subsection{Plywood production}

Rotary cut beech (Fagus sylvatica $\mathrm{L}$.) veneers with the dimension of $1.5 \times 400 \times 400 \mathrm{~mm}^{3}(\mathrm{R} \times \mathrm{L} \times \mathrm{T})$ were impregnated in an autoclave under vacuum (60 mbar) for $30 \mathrm{~min}$ utes and subsequently under pressure (12 bar) for $2 \mathrm{~h}$ using the following solutions: (1) $N$-methylol-melamine (NMM) solution (NMM-1, 10\% solid content); (2) fatty acid modified NMM dispersions containing paraffin (mNMM-2, 5\% solid content) with catalyst RB (1.7\% based on the commercial stock solution of mNMM-2). Water impregnated veneers were used for control plywood. The impregnated veneers were pre-dried at $40^{\circ} \mathrm{C}(24 \mathrm{~h})$ to a moisture content of $3-8 \%$ prior to the following processes:

Process 1 The veneers were cured for 5 minutes in a hot press at $130^{\circ} \mathrm{C}$ and $1 \mathrm{MPa}$ specific pressure. Before gluing, the veneers were conditioned at room temperature for 4 days until the moisture content of the veneers was between 3 and $8 \%$. An amount of $160 \mathrm{~g} \mathrm{~m}^{-2} \mathrm{PF}$ resin was applied on one side of four of the five veneers using a roller. Afterwards, 5-layer-plywood was produced in a hot press $\left(130^{\circ} \mathrm{C}\right)$ at 1.5 MPa specific pressure (10 min pressing time).

Process 2 The procedure was the same as in process 1, but curing of the veneers and hot pressing (to produce plywood) were combined in the hot pressing step. The prepared plywood samples were conditioned at $20^{\circ} \mathrm{C}$ and $65 \% \mathrm{RH}$ for 3 days before being cut to the required sizes for the various mechanical tests.

\subsection{Bonding quality}

The shear strength and cohesive wood failure (accuracy of $5 \%$ ) of the plywood was assessed according to EN 314-1 (2004). Prior to the test, 36 plywood specimens from each treatment were pre-treated as specified in part 5.1.1, 5.1.3, and 5.1.4 of EN 314-1 (2004).

Based on the mean values of shear strength and the mean values of cohesive wood failure, bonding quality of the plywood was classified as described in EN 314-2 (1993).

\subsection{Modulus of rupture (MOR) and modulus of elasticity (MOE)}

Modulus of rupture (MOR) and modulus of elasticity (MOE) were determined according to EN 310 (1993). Two sets of 10 specimens from each treatment were cut from the plywood: specimens with the grain of the upper layer parallel to the longitudinal axis, and specimens with the grain of the upper layer perpendicular to the longitudinal axis.

\subsection{Brinell hardness}

The determination of Brinell hardness was carried out according to EN 1534 (2000) for 12 plywood specimens of $7.5 \times 50 \times 50 \mathrm{~mm}^{3}$ per treatment. Brinell hardness was measured at 5 symmetrically distributed points on each specimen.

\subsection{Water submersion/oven-drying test}

Water uptake and dimensional stability were evaluated according to a modified procedure from EN 317 (1993). Ten plywood specimens of $7.5 \times 50 \times 50 \mathrm{~mm}^{3}$ from each treatment were dried at $103^{\circ} \mathrm{C}$ prior to the submersion/ovendrying cycling test. Each cycle consisted of six steps: 1. submersion in water $(24 \mathrm{~h}), 2$. water soaking under vacuum (60 mbar, $1 \mathrm{~h})$ and storing under water $(20 \mathrm{~h})$, 3. air-drying $(24 \mathrm{~h}), 4$. oven-drying $\left(50^{\circ} \mathrm{C}, 24 \mathrm{~h}\right), 5$. oven-drying $\left(80^{\circ} \mathrm{C}\right.$, $24 \mathrm{~h}), 6$. oven-drying $\left(103^{\circ} \mathrm{C}, 24 \mathrm{~h}\right)$ and cooling to room temperature over silica gel in a desiccator. The cycle was repeated six times. The specimens were totally dry after the last step of each cycle at $103^{\circ} \mathrm{C}$. Mass and thickness of the specimens were determined after steps 1 and 6 . Water uptake and thickness swelling were calculated from the ratio of the values at the wet state and the dry state from each cycle.

The water repellent effectiveness (WRE) and thickness swelling reduction (TSR) were calculated from the water uptake and thickness swelling of the control plywood specimens $\left(W U_{c}, T S_{c}\right)$ and of the treated plywood specimens $\left(W U_{t}, T S_{t}\right)$ during the same submersion cycle.

$W R E[\%]=\frac{\left(W U_{c}-W U_{t}\right)}{W U_{c}} \times 100$

$\operatorname{TSR}[\%]=\frac{\left(T S_{c}-T S_{t}\right)}{T S_{c}} \times 100$

The number of delaminated specimens was determined after each cycle.

\subsection{Sorption behavior}

The equilibrium moisture content (EMC) associated with changes in RH was determined following a modified procedure from EN 318 (2002) and from EN 323 (1993). Two sets of 10 plywood specimens of $7.5 \times 50 \times 50 \mathrm{~mm}^{3}$ were prepared for each treatment. One set was conditioned for an absorption process at 30,65 , and $85 \% \mathrm{RH}\left(20^{\circ} \mathrm{C}\right)$ and the other set was conditioned for a desorption process at 85, 65, and $30 \% \mathrm{RH}\left(20^{\circ} \mathrm{C}\right)$ in climate chambers. The weight of the plywood specimens was recorded when the EMC was reached at the respective RH. EMC calculation was based on the weight after conditioning and dry weight of the plywood. 


\subsection{Formaldehyde emission}

The determination of formaldehyde emission by the flask method was conducted according to EN 717-3 (1996). As soon as the plywood boards had cooled down after hot pressing, the boards were cut into 35 specimens of $7.5 \times 25 \times$ $25 \mathrm{~mm}^{3}$. Ten of these specimens were used to determine the moisture content. The other 25 specimens divided randomly into five sets (five specimens per set, weight of each set was approx. $20 \mathrm{~g}$ ) were used for the determination of formaldehyde content. Each set was suspended in a closed flask over distilled water; the flasks were placed in an oven at $40^{\circ} \mathrm{C}$ for $3 \mathrm{~h}$.

\subsection{Statistical analysis}

Statistical analysis was applied to compare all determined properties of the plywood produced from process 1 and 2 . Since the data were not normally distributed, the results were analysed using the non-parametric Mann-Whitney-U test (Hill and Lewicki 2007).

\section{Results and discussion}

\subsection{Weight percent gain}

The weight percent gain (WPG) of the veneers treated with $10 \%$ NMM- 1 was $10.4 \pm 1.0 \%$; that of veneers treated with $5 \%$ mNMM-2 was $4.6 \pm 0.2 \%$.

\subsection{Bonding quality}

The treatment with NMM compounds is not expected to reduce the number of hydroxyl groups in the treated wood.
Accordingly, the treatment does not decrease the possibility of hydrogen bonding of the wood substrate with the adhesive due to chemical blocking. It is assumed that of the two $\mathrm{N}$ methylol-melamine (NMM) compounds tested in this study only NMM-1 is partly able to penetrate the cell wall and impart dimensional stability (Lukowsky 2002). The second formulation (mNMM-2), however, is most probably only deposited in the lumens of the wood cells due to the large diameters of both the fatty acid modified NMM and the paraffin as well as particularly of the dispersion particles formed thereof. It should therefore not change the vapour sorption and swelling behavior of the cell wall, but was shown to reduce the capillary water uptake of solid wood (Nguyen et al. 2007). This was the reason why mNMM-2 was applied in a lower concentration than NMM-1. Regardless of the production process and pre-treatment, the plywood treated with NMM-1 solution resulted in higher shear strength, whereas the treatment with the mNMM-2 dispersion diminished the shear strength of the plywood as compared to the control plywood (Fig. 1). Still, the shear strength was higher than $1 \mathrm{~N} \mathrm{~mm}^{-2}$ in all cases except for mNMM-2 treated plywood in process 1 . The failure of the test plywood specimens occurred in the wood parts or in the bond lines between the saw cuts (within the shear test area) for both processes. Hence, the results of these shear tests were accepted according to the requirements of the standard EN 314-1 (2004).

The percentage of cohesive wood failure in the control plywood varied from 50 to $100 \%$, while it was lower in the treated plywood $(0-40 \%)$ in both process 1 and process 2 ; the mean values displayed a high standard deviation (Table 1). According to the standard EN 314-2 (1993), plywood used in class 3 (non-cover exterior use) must satisfy both criteria on shear strength and cohesive wood failure; however, if the mean shear strength is higher than $1 \mathrm{~N} \mathrm{~mm}^{-2}$, there is no requirement related to cohesive wood failure. Thus, the

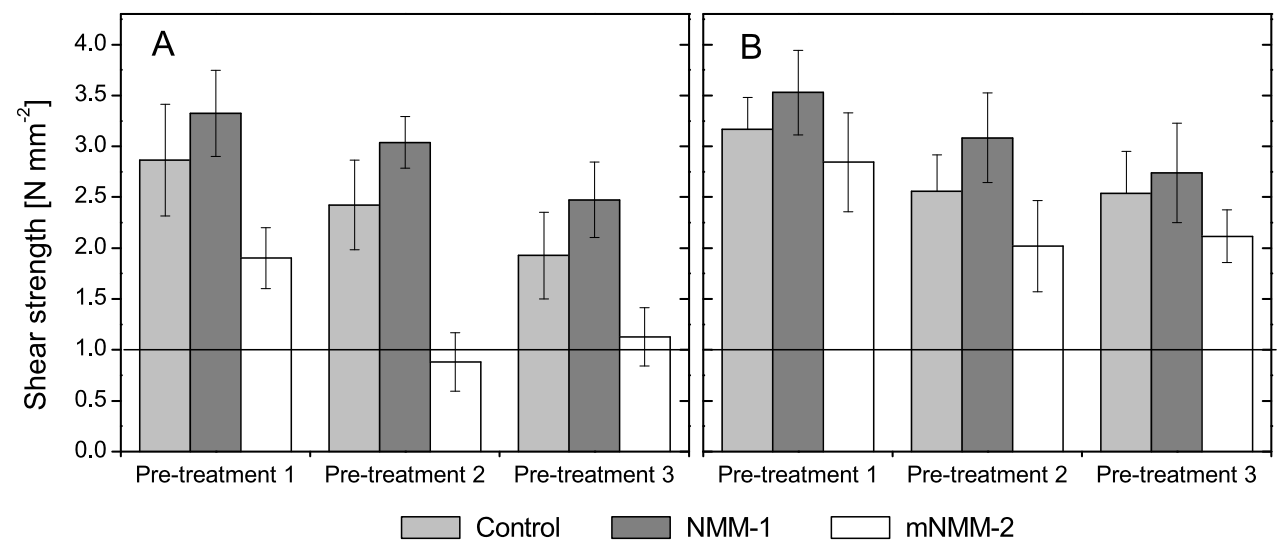

Fig. 1 Shear strength of the control and treated plywood, process 1 (A) and process $2(\mathbf{B})(n=12$, mean values $\pm \mathrm{SD})$. The line at $1.0 \mathrm{Nm} \mathrm{m}^{-2}$ indicates the requirement for plywood to be used in non-covered exterior conditions (class 3 according to EN 314-2 1993)

Abb. 1 Scherfestigkeit von Kontroll- und behandeltem Sperrholz, Prozess 1 (A) und Prozess 2 (B) $(n=12$, Mittelwert \pm STD). Die Linie bei $1,0 \mathrm{~N} \mathrm{~m}^{-2}$ zeigt die Anforderung an Sperrholz zur Benutzung im Außenbereich (Klasse 3 gemäß EN 314-2 1993) 
Table 1 Cohesive wood failure ( \pm SD) of the control and treated plywood after different pre-treatments with water according to EN 314-1 (2004): pre-treatment 1: according to 5.1.1; pre-treatment 2: according to 5.1.3; and pre-treatment 3: according to 5.1.4. $C_{1}, C_{2}$ : Control, process 1 or $2 ; M_{1}, M_{2}$ : NMM-1-treated plywood-process 1 or $2 ; V_{1}$, $V_{2}$ : mNMM-2 treated plywood-process 1 or 2 . All values represent mean values \pm standard deviation $(n=12)$

Tab. 1 Holzbruchanteil ( \pm STD) von Kontroll- und behandeltem Sperrholz nach verschiedenen Vorbehandlungen in Wasser gemäß EN 314-1 (2004): Vorbehandlung 1: gemäß 5.1.1; Vorbehandlung 2: gemäß 5.1.3 und Vorbehandlung 3 gemäß 5.1.4. $C_{1}, C_{2}$ : Kontrolle, Prozess 1 und 2; $M_{1}, M_{2}$ : NMM 1-behandeltes Sperrholz - Prozess 1 oder 2; $V_{1}, V_{2}$ : mNMM-2-behandeltes Sperrholz - Prozess 1 oder 2. Alle Werte zeigen Mittelwerte \pm Standardabweichung $(n=12)$

\begin{tabular}{llll}
\hline Treatment & \multicolumn{2}{l}{ Cohesive wood failure [\%] } \\
\cline { 2 - 4 } & Pre-treatment 1 & Pre-treatment 2 & Pre-treatment 3 \\
\hline$C_{1}$ & $66 \pm 27$ & $67 \pm 31$ & $76 \pm 27$ \\
$C_{2}$ & $58 \pm 31$ & $57 \pm 28$ & $60 \pm 22$ \\
$M_{1}$ & $15 \pm 13$ & $26 \pm 15$ & $24 \pm 14$ \\
$M_{2}$ & $15 \pm 11$ & $26 \pm 17$ & $31 \pm 14$ \\
$V_{1}$ & $3 \pm 4$ & $3 \pm 3$ & $9 \pm 5$ \\
$V_{2}$ & $13 \pm 13$ & $16 \pm 6$ & $11 \pm 7$ \\
\hline
\end{tabular}

plywood of both processes (except mNMM-2-treated plywood in process 1) met the requirements for non-covered exterior conditions (class 3 ). The Mann-Whitney-U test indicated that the plywood made in process 2 displayed comparable or higher shear strength than that produced in process 1 (Table 2). This indicates that curing prior to pressing (process 1) did not bring about any significant difference of bonding quality as compared to pressing without precuring (process 2) with respect to NMM-1 treatment. NMM1-treated plywood always displayed a tendency to increased shear strength but a reduction of cohesive wood failure as compared to those of the control plywood. This implies that in the control samples the bond strength was restricted by the wood strength and that the treatment with NMM-1 enhanced the wood strength. However, it cannot be concluded that the adhesion, defined as the forces between the wood surface and the adhesive layer, was increased due to the treatment with NMM-1, because the cohesive wood failure of the treated samples was lower as compared to the controls. Enhanced strength properties of NMM-treated solid wood have been reported previously (Deka and Saikia 2000; Gindl et al. 2004; Inoue et al. 1993).

In contrast to NMM-1, the treatments with mNMM-2 induced a clear reduction in both shear strength and cohesive wood failure. Plywood specimens produced in process 1 displayed clearly lower values with regard to both properties than those produced in process 2 (Fig. 1, Table 1). Curing prior to gluing might increase the surface energy (not tested) and reduce the penetration depth of the adhesive and, thus, the area of the two-dimensional interface which forms the border between the wood surface and the adhesive layer on
Table 2 Statistic comparison of shear strength with respect to different pre-treatments according to EN 314-1 (2004), and of Brinell hardness between process 1 and process 2 (Mann-Whitney-U test, $p=0.05$ ). Treatments and processes are defined in Table 1

Tab. 2 Statistischer Vergleich der Scherfestigkeit in Bezug auf verschiedene Vorbehandlungen gemäß EN 314-1 (2004) und der Brinellhärte zwischen Prozess 1 und 2 (Mann-Whitney-U-Test, $p=0.05$ ). Die Behandlungen und Prozesse sind in Tabelle 1 definiert

Shear strength $\left[\mathrm{N} \mathrm{mm}^{2}\right]$

\begin{tabular}{llll}
\hline Pre-treatment 1 & Pre-treatment 2 & Pre-treatment 3 & Brinell hardness \\
\hline$C_{1}=C_{2}$ & $C_{1}=C_{2}$ & $C_{1}<C_{2}$ & $C_{1}<C_{2}$ \\
$M_{1}=M_{2}$ & $M_{1}=M_{2}$ & $M_{1}=M_{2}$ & $M_{1}=M_{2}$ \\
$V_{1}<V_{2}$ & $V_{1}<V_{2}$ & $V_{1}<V_{2}$ & $V_{1}>V_{2}$ \\
\hline
\end{tabular}

a molecular scale. The aforementioned factors are considered to be the main reasons for the reduction of PF adhesion due to over-drying (Christiansen 1990, 1991).

Chemical modification, which replaces polar hydroxyl groups of wood with more non-polar groups, is supposed to reduce adhesion by making the wood surface less polar and less porous, resulting in poorer adhesive wetting and less bonding possibilities (hydrogen bonding, van der Waals interactions) between the two surfaces (Hunt et al. 2007; Kamke and Lee 2007). In addition, the more polar the adhesive at the same molecular structure and molar masses, the better is the penetration into the untreated wood structure (Rowell 1995). The PF adhesive may penetrate into the cell lumens and cell walls of wood and thus enlarge the bonding interface. The treatment of wood with NMM-1 might reduce the surface energy and restrain the penetration of the PF adhesive into the wood pores. On the other hand, NMM-1 possesses $N$-methylol and amine groups which can potentially react with PF to form covalent bonds; NMM, however, is unlikely to be covalently bonded to the wood surface.

NMM-1 might also dimensionally stabilise the wood surface under wet conditions as it was recently suggested for priming with hydroxymethylated resorcinol (Son and Gardner 2004; Gardner et al. 2006), and thus increase the wet shear strength.

In contrast to NMM-1, mNMM-2 mostly acts as a hydrophobation agent because of its content of fatty acids and paraffin. It does not penetrate deeply into the wood and mainly concentrates at the surface due to relatively large diameters of the dispersion particles. It is assumed that it reduces both the surface energy and the adhesive penetration to a greater extent than NMM-1. The possibility of covalent bonding of the fatty acid modified NMM (mNMM-2) with the PF resin is also less than with NMM-1 because of the lower concentration and the substitution of the melamine component with fatty acid moieties.

The investigation into bonding quality of $N$-methylol melamine treated wood has not yet been reported in the literature. In a comparable work on beech plywood treated with 
Fig. 2 Modulus of rupture (MOR) and modulus of elasticity (MOE) of the control and treated plywood, process 1 $(\mathbf{A}, \mathbf{C})$ and process $2(\mathbf{B}, \mathbf{D})$ $(n=10$, mean values $\pm \mathrm{SD})$ Abb. 2 Biegefestigkeit (MOR) und Elastizitätsmodul (MOE) von Kontroll- und behandeltem Sperrholz, Prozess $1(\mathbf{A}, \mathbf{C})$ und Prozess $2(\mathbf{B}, \mathbf{D})(n=10$, Mittelwert \pm STD)

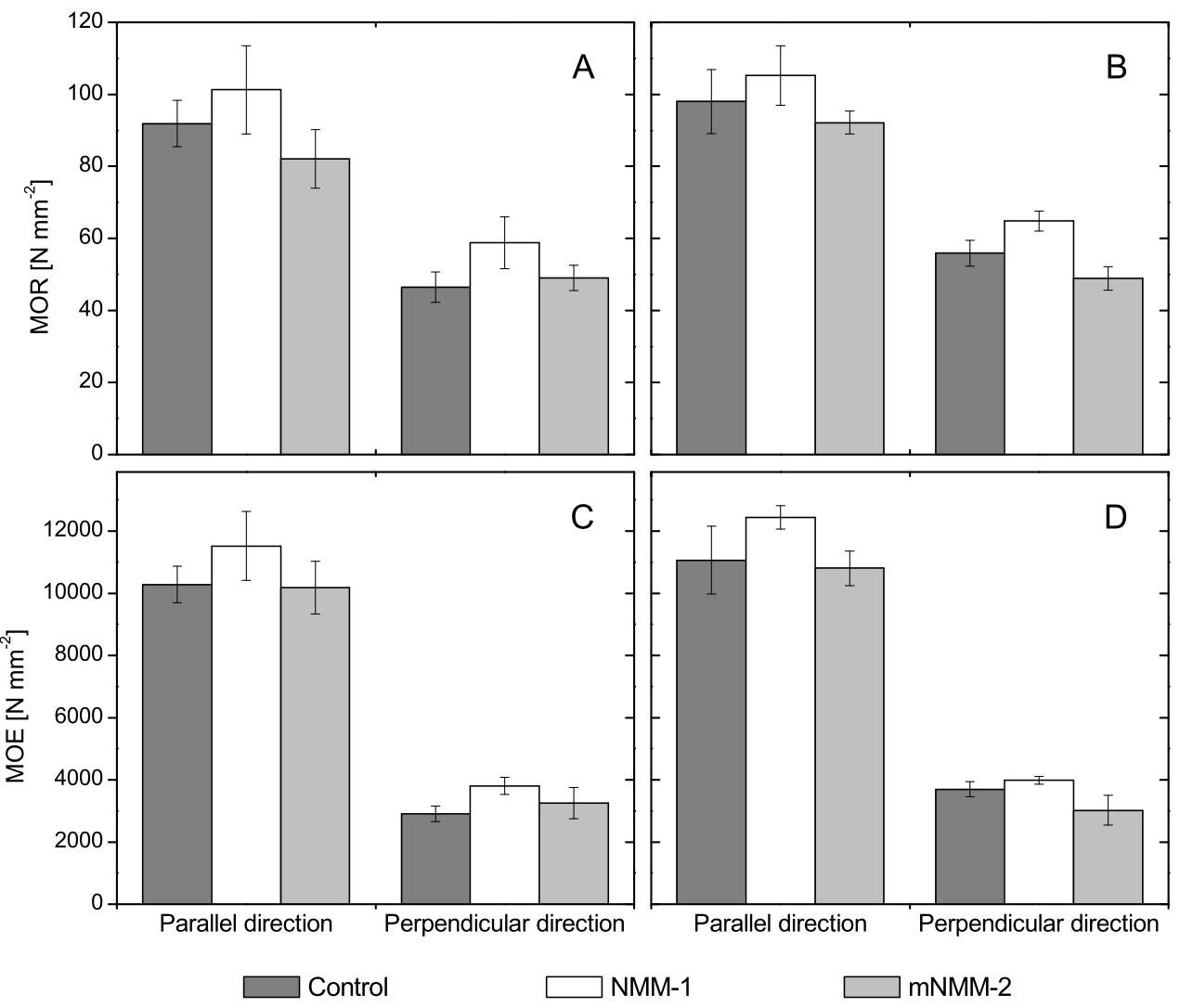

1,3-dimethylol-4,5-dihydroxyethyleneurea (DMDHEU), the control plywood presented significantly higher shear strength (1.4 times) and higher percentage of cohesive wood failure than the treated plywood (Dieste et al. 2009). Vick and Rowell (1990) also found a reduction in bonding strength of acetylated yellow poplar veneers glued with a PF resin when compared to the controls. Lowering wettability and permeability due to the substitution of hydroxyl groups of cell wall polymers by acetyl groups was assumed to be the main reason for the poor performance of phenolic resins on acetylated wood.

\subsection{Modulus of rupture in bending (MOR) and modulus of elasticity (MOE)}

As expected, both the modulus of rupture (MOR) and the modulus of elasticity (MOE) of the tested plywood samples were higher when the longitudinal axis of the test specimen was parallel to the grain direction of the middle layer (parallel direction) (Fig. 2). Regardless of the plywood production process and the grain direction, NMM-1-treated plywood always exhibited some increase in MOR and MOE compared to those of the controls and the mNMM-2-treated specimens. MOR of plywood is determined mainly by the bonding strength caused by the adhesive and by the strength of the veneers, while that of the veneers themselves is a consequence of compression and tensile strength (Dieste et al.
2008). As already mentioned above (Fig. 1), NMM-1 treatment increased the bonding strength of the plywood samples. As a minor effect, the treatment might also have increased the MOR of the veneers, because the increased hardness (see Fig. 3 below) indicates an increase in compression strength, while the tensile strength was not affected by the treatment (Trinh 2009). Improvements in MOR and MOE of solid wood due to the treatment with NMM compounds have been reported previously (Deka and Saikia 2000; Deka et al. 2000; Inoue et al. 1993); however, Inoue et al. (1993) indicated a slight decrease in MOR and MOE at a NMM concentration below 5\%. MOR and MOE of plywood treated with mNMM-2 did not show significant differences from those of the controls. Solid wood specimens treated with mNMM-2 at higher concentrations as used in this study did not yield any significant changes in MOR and MOE (Nguyen 2008), although an aluminium salt was used as a catalyst which could diminish the strength of the wood (Trinh 2009). As observed for the NMM compounds used in this study, the treatment of veneers with DMDHEU did not induce considerable changes in MOR and MOE of plywood as compared to the controls (Dieste et al. 2008). Acetylation of veneers to a WPG of $16.3 \%$ did not affect MOR and MOE, whereas Talaei (2008) reported significantly reduced values for both compared to untreated control plywood at a treatment yielding 20.0\% WPG. A reduction in MOR and MOE, if at all present, can be attributed to a reduction in bonding 


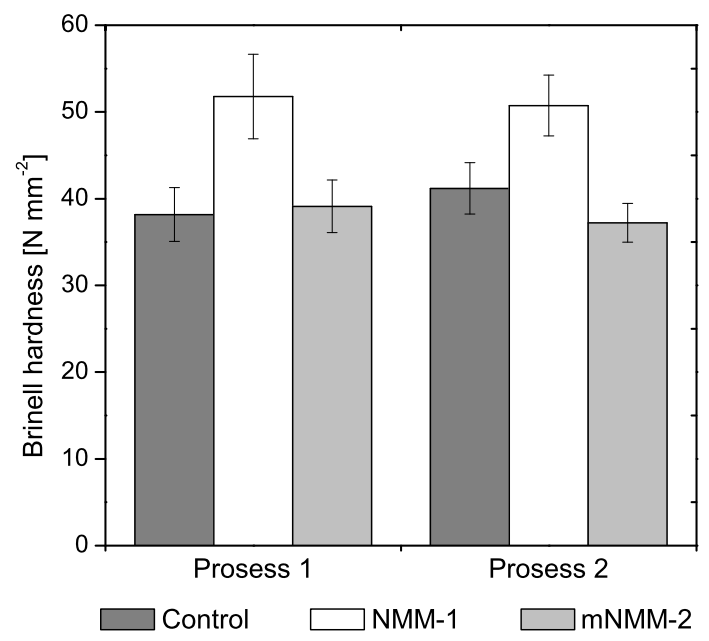

Fig. 3 Brinell hardness of the control and treated plywood produced in process 1 and process $2(n=12$, mean values \pm SD)

Abb. 3 Brinellhärte von Kontroll- und behandeltem Sperrholz hergestellt nach Prozess 1 und $2(n=12$, Mittelwert \pm STD $)$

Table 3 Statistic comparison of MOR and MOE between process 1 and process 2 (Mann-Whitney-U test, $p=0.05$ ). Treatments and processes are defined in Table 1

Tab. 3 Statistischer Vergleich der Biegefestigkeit und des Elastizitätsmoduls zwischen Prozess 1 und 2 (Mann-Whitney-U-Test, $p=0,05$ ). Die Behandlungen und Prozesse sind in Tabelle 1 definiert

\begin{tabular}{lllll}
\hline MOR & & & MOE & \\
\cline { 1 - 1 } $\begin{array}{l}\text { Parallel } \\
\text { direction }\end{array}$ & $\begin{array}{l}\text { Perpendicular } \\
\text { direction }\end{array}$ & & $\begin{array}{l}\text { Parallel } \\
\text { direction }\end{array}$ & $\begin{array}{l}\text { Perpendicular } \\
\text { direction }\end{array}$ \\
\hline$C_{1}=C_{2}$ & $C_{1}<C_{2}$ & & $C_{1}=C_{2}$ & $C_{1}<C_{2}$ \\
$M_{1}=M_{2}$ & $M_{1}<M_{2}$ & & $M_{1}<M_{2}$ & $M_{1}<M_{2}$ \\
$V_{1}<V_{2}$ & $V_{1}=V_{2}$ & & $V_{1}=V_{2}$ & $V_{1}=V_{2}$ \\
\hline
\end{tabular}

strength as observed by Vick and Rowell (1990) (as mentioned above). The statistic comparisons of MOR and MOE between process 1 and 2 revealed that the values for process 1 were lower or equal to those in process 2 (Table 3). Reductions are attributed to the lower bonding strength of the plywood in process 1 .

\subsection{Hardness (Brinell)}

The NMM-1-treated plywood revealed clearly higher Brinell hardness than the control and the mNMM-2-treated plywood (Fig. 3). Treatment with an $N$-methylol melamine solution was previously shown to increase the Brinell hardness of solid wood (Inoue et al. 1993; Gindl et al. 2004). The diffusion of NMM-1 molecules into the cell wall and polycondensation at that place most obviously is the main reason for the increased hardness of solid wood and of the plywood, where hardness is tested as property of the face layer veneer. The modification of veneers with an aqueous solution of DMDHEU (0.8-1.3 mol $\left.\mathrm{l}^{-1}\right)$ also increased the hardness of beech plywood to an extent similar to that of the plywood treated with NMM-1 solution in this study (Dieste et al. 2008). The authors showed that the hardness increases with increasing treatment concentration of DMDHEU. The plywood treated with mNMM-2, however, did not exhibit significant improvement of hardness in comparison to the controls. Nguyen (2008) reported previously that even the treatment with higher concentrations of mNMM-2 did not result in a significant change of Brinell hardness in the radial direction of solid Scots pine sapwood and beech wood. This is attributed to the fact that mNMM-2 is not able to penetrate into the cell wall. The statistical analyses for mNMM-2 treated plywood displayed a slightly higher hardness in process 1 in comparison to process 2 (Table 2). The hardness values of the plywood treated with NMM-1 were the same in both processes.

\subsubsection{Water uptake, thickness swelling and delamination due to water submersion/oven-drying cycles}

Cyclic water submersion and oven-drying was performed in order to test the water repellence and the long-term dimensional stability of the plywood (Borgin 1965; Hill and Jones 1996). The treatment of the veneers with both types of NMM compounds clearly reduced the water uptake (WU) of the produced plywood after $24 \mathrm{~h}$ submersion compared to the controls (Fig. 4A, B). This effect was stable over 6 cycles of submersion and drying with an exception of the mNMM-2 specimens treated in process 1 (hardening before pressing) due to plywood delamination. The early delamination of the latter specimens is attributed to the low bonding quality as shown in Fig. 1. WU during the first submersion was in most cases still slightly lower than after the following cycles. Despite of the achieved WPG, mNMM-2 was more efficient than NMM-1 in reducing the water uptake; the average water repellent effectiveness (WRE) during the second to the sixth submersion was approximately $30 \%$ for NMM-1, but $65 \%$ for mNMM-2-treated plywood in case of process 2 (Fig. 4C, D). This is attributable to the additional hydrophobic effect of the content of fatty acid and of paraffin in the mNMM-2 dispersion. The reduction of WU can be explained by the lower wettability and the occlusion of the main penetration paths for water such as ray cells by both NMM compounds (Nguyen et al. 2007; Gindl et al. 2004) and with partial incorporation of NMM-1 into the cell wall (Gindl et al. 2004). The thickness swelling (TS) displayed a comparable tendency as observed for the water uptake. NMM-1 reduced TS to a minor degree as mNMM-2 did (Fig. 5A, B).

The thickness swelling reduction (TSR) decreased with increasing number of submersion cycles for both chemical treatments (Fig. 5C, D). The statistical analyses did not show any significant differences in WU and TS between process 
Fig. 4 Water uptake (A, B) and water repellent effectiveness (WRE; C, D) after $24 \mathrm{~h}$ submersion of the control and treated plywood during a cycling submersion and oven-drying procedure; process $1(\mathbf{A}, \mathbf{C})$ and process $2(\mathbf{B}, \mathbf{D})$ $(n=10$, mean values $\pm \mathrm{SD})$

Abb. 4 Wasseraufnahme (A, B) und Wirksamkeit der Wasserabstoßung (WRE; C, D) von Kontroll- und behandeltem Sperrholz nach 24-stündigem Tauchen während eines zyklischen Tauch- und Ofentrocknungstests, Prozess 1 $(\mathbf{A}, \mathbf{C})$ und Prozess $2(\mathbf{B}, \mathbf{D})$ $(n=10$, Mittelwert \pm STD $)$
Fig. 5 Thickness swelling (A, B) and thickness swelling reduction (TSR; C, D) after $24 \mathrm{~h}$ submersion of the control and treated plywood during a cycling submersion and oven-drying procedure; process $1(\mathbf{A}, \mathbf{C})$ and process $2(\mathbf{B}, \mathbf{D})$ $(n=10$, mean values $\pm \mathrm{SD})$ Abb. 5 Dickenquellung (A, B) und Reduktion der

Dickenquellung (TSR; C, D) von Kontroll- und behandeltem Sperrholz nach 24-stündigem Tauchen während eines zyklischen Tauch- und Ofentrocknungstests, Prozess 1 $(\mathbf{A}, \mathbf{C})$ und Prozess $2(\mathbf{B}, \mathbf{D})$ $(n=10$, Mittelwert \pm STD $)$
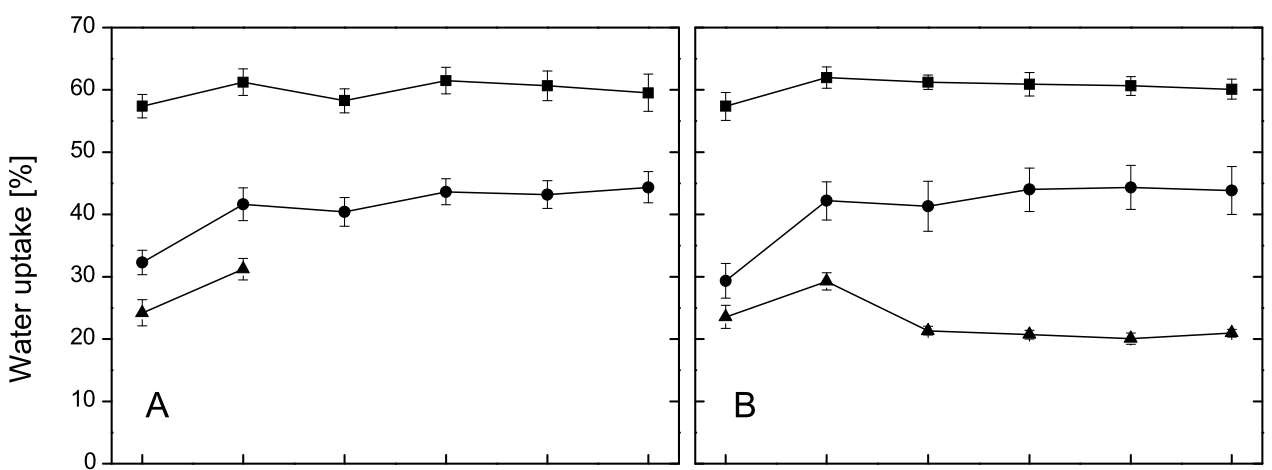

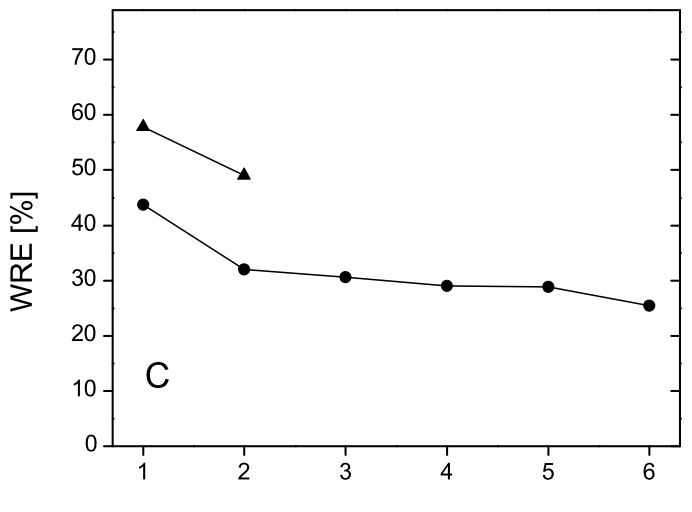

Number of cycles

- Control

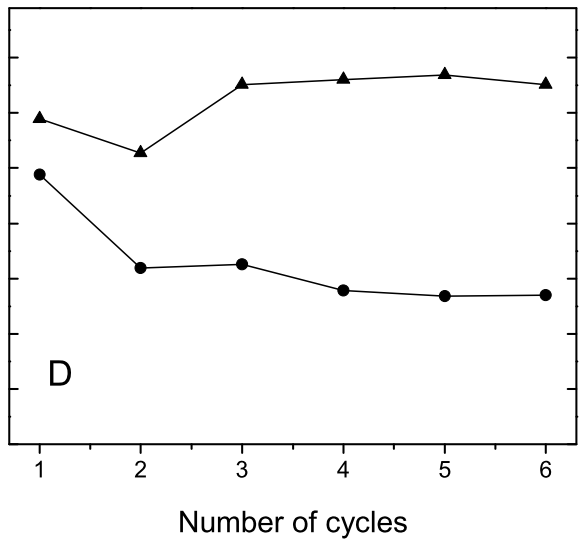

NMM-1

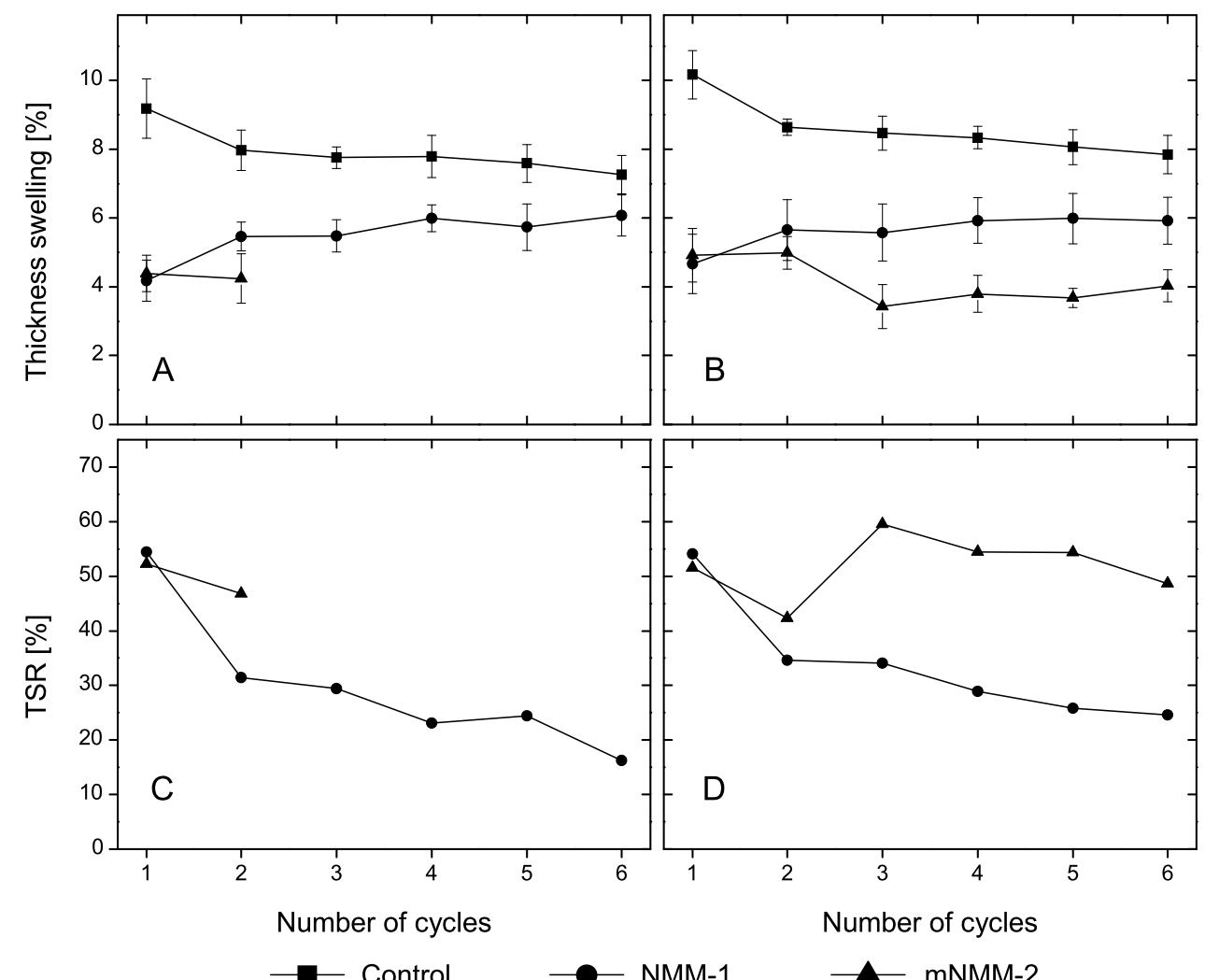


Table 4 Number of delaminated specimens of the control and treated plywood after individual cycles of water submersion and oven-drying Tab. 4 Zahl der delaminierten Proben des Kontroll- und behandelten Sperrholzes nach einzelnen Zyklen des Tauch- und Ofentrocknungstests

\begin{tabular}{|c|c|c|c|c|c|c|c|c|c|c|c|c|}
\hline \multirow[t]{2}{*}{ Number of cycles } & \multicolumn{6}{|c|}{ Process 1} & \multicolumn{6}{|c|}{ Process 2} \\
\hline & 1 & 2 & 3 & 4 & 5 & 6 & 1 & 2 & 3 & 4 & 5 & 6 \\
\hline Control & 0 & 0 & 0 & 0 & 0 & 2 & 0 & 0 & 0 & 0 & 0 & 1 \\
\hline NMM-1 & 0 & 0 & 0 & 0 & 0 & 0 & 0 & 0 & 0 & 0 & 0 & 0 \\
\hline mNMM-2 & 5 & 10 & 10 & 10 & 10 & 10 & 0 & 0 & 0 & 0 & 0 & 2 \\
\hline
\end{tabular}

1 and 2 for the control plywood at all submersion cycles, although it is known that minor changes in structural cell wall polymers may occur at temperatures above $130^{\circ} \mathrm{C}$ (Hill 2006; Kollmann and Fengel 1965). In addition, both types of NMM-treated plywood did not display any significant difference in WU and TS between process 1 and 2. Hence, curing prior to pressing did not impart any improvement in water repellence and dimensional stability for the treated plywood. Pre-curing was regarded as the optimum treatment for the veneers. Thus, better performance of the pre-cured specimens was expected initially, because it was assumed that the degree of condensation and cross-linking of the NMMs would be higher.

The soaking and drying cycles caused swelling and shrinking stresses for the plywood specimens. As a result, the bonding strength was reduced, and the specimens started delaminating during the cyclic test. Among the controls only two (process 1) and one (process 2) of ten plywood specimens delaminated during the sixth cycle (Table 4). In case of the NMM-1 treated plywood delamination was not observed irrespective of the production process. All mNMM2 treated plywood specimens of process 1 delaminated already after the second cycle, while only two of those produced in process 2 delaminated during the sixth cycle (Table 4). The quantity of delaminated plywood specimens during the water submersion cycles showed a similar trend to the bonding quality (Fig. 1). The differences in swelling are attributable to the hydrophobation of the veneers on the one hand and to the bonding strength on the other hand. Although the mNMM-2-treated plywood produced in process 2 exhibited a lower bonding strength than the NMM1-treated specimens, the hydrophobing effect of mNMM-2 had a stronger influence on thickness swelling than that of NMM-1. These results also show that the repellence of water has a major effect on thickness swelling as compared to dimensional stabilisation of the wood cell wall, since, in contrast to NMM-1, mNMM-2 is not able to penetrate the cell wall.

\subsubsection{Equilibrium moisture content}

The equilibrium moisture content (EMC) of the plywood at $20^{\circ} \mathrm{C}$ and different $\mathrm{RH}$ was determined for adsorption and desorption of moisture. Moisture (vapour) sorption is a process which proceeds due to the uptake and incorporation of water molecules into the cell wall, whereas no water is deposited in the lumens of the cells. For this reason, moisture sorption can only be reduced, when hydroxyl groups of cell wall polymers are replaced by less polar groups or when chemicals are stably incorporated in the cell wall matrix and fill cell wall nano-pores (Xie et al. 2010).

NMM-1-treated plywood always imparted the lowest EMC (Tables 5, 6). The reduction caused by NMM-1, however, was only somewhat higher than the WPG (10.4\%) of the treated veneers and is therefore attributed mostly to the higher mass of the veneers. Deposition of NMM-1 in the cell wall and the filling of nano-pores might be regarded as a minor reason for the reduction in EMC. The EMC of mNMM-2-treated plywood was only slightly reduced compared to the control plywood. The reduction in EMC due to mNMM-2-treatment is exclusively attributed to the higher mass of the veneers as compared to the controls, because the constituents of the formulation are not able to penetrate the cell wall. The different processes of plywood production did not result in significantly different EMC values.

Hydrophobation by, e.g., waxes or other nonpolar compounds generally block the main penetration pathways for the ingress of liquid water (pores in the wood, the adhesive or in the interface between those). Deposition of hydrophobing agents in the lumens can therefore reduce the uptake of liquid water, but cannot lower the moisture sorption by the cell wall and, thus, the EMC (Donath et al. 2007). This was also observed for the two NMM compounds, particularly for mNMM-2.

\subsubsection{Formaldehyde emission}

One of the advantages of phenolic resins as compared to urea-formaldehyde or melamine-urea-formaldehyde resins is a very low emission of formaldehyde in service due to the high number of stable methylene bridges between the aromatic nuclei and the low number of residual methylol $\left(-\mathrm{CH}_{2}-\mathrm{OH}\right)$ groups after hardening (Dunky 2003; Roffael 2006). Methylene bridges (melamine- $\mathrm{NH}-\mathrm{CH}_{2}-\mathrm{NH}-$ melamine) are described as being more stable than ether bridges (melamine- $\mathrm{NH}-\mathrm{CH}_{2}-\mathrm{O}-\mathrm{CH}_{2}-\mathrm{NH}$-melamine) between melamine molecules (Blank 1979; Scheepers et al. 1993; Aarts et al. 1995).

The plywood produced from modified veneers emitted considerably higher amounts of formaldehyde than the controls (Fig. 6). The highest values were found in the case of the NMM-1-treated specimens (12-20 times higher than 
Table 5 Equilibrium moisture content (EMC) of the adsorption process $(n=10 \pm \mathrm{SD})$

Tab. 5 Gleichgewichtsfeuchten (EMC) des

Adsorptionsprozesses $(n=10$ \pm STD)

Table 6 Equilibrium moisture content (EMC) of the desorption process $(n=10 \pm \mathrm{SD})$

Tab. 6 Gleichgewichtsfeuchten (EMC) des

Desorptionsprozesses $(n=10 \pm$ STD)

\begin{tabular}{|c|c|c|c|c|c|c|}
\hline \multirow[t]{2}{*}{ Treatment } & \multicolumn{2}{|c|}{$30 \% \mathrm{RH}, 20^{\circ} \mathrm{C}$} & \multicolumn{2}{|c|}{$65 \% \mathrm{RH}, 20^{\circ} \mathrm{C}$} & \multicolumn{2}{|c|}{$85 \% \mathrm{RH}, 20^{\circ} \mathrm{C}$} \\
\hline & Process 1 & Process 2 & Process 1 & Process 2 & Process 1 & Process 2 \\
\hline Control & $5.5 \pm 0.1$ & $5.6 \pm 0.1$ & $10.4 \pm 0.1$ & $10.4 \pm 0.1$ & $16.9 \pm 0.3$ & $17.3 \pm 0.1$ \\
\hline NMM-1 & $5.4 \pm 0.1$ & $5.5 \pm 0.1$ & $9.1 \pm 0.1$ & $9.3 \pm 0.1$ & $14.1 \pm 0.2$ & $14.2 \pm 0.4$ \\
\hline mNMM-2 & $5.5 \pm 0.1$ & $5.6 \pm 0.2$ & $9.9 \pm 0.1$ & $10.0 \pm 0.2$ & $16.2 \pm 0.2$ & $16.6 \pm 0.2$ \\
\hline
\end{tabular}

\begin{tabular}{|c|c|c|c|c|c|c|}
\hline \multirow[t]{2}{*}{ Treatment } & \multicolumn{2}{|c|}{$85 \% \mathrm{RH}, 20^{\circ} \mathrm{C}$} & \multicolumn{2}{|c|}{$65 \% \mathrm{RH}, 20^{\circ} \mathrm{C}$} & \multicolumn{2}{|c|}{$30 \% \mathrm{RH}, 20^{\circ} \mathrm{C}$} \\
\hline & Process 1 & Process 2 & Process 1 & Process 2 & Process 1 & Process 2 \\
\hline Control & $17.2 \pm 0.2$ & $17.4 \pm 0.5$ & $11.4 \pm 0.1$ & $11.5 \pm 0.1$ & $6.9 \pm 0.3$ & $6.6 \pm 0.1$ \\
\hline NMM-1 & $14.7 \pm 0.5$ & $14.1 \pm 0.1$ & $10.4 \pm 0.1$ & $10.3 \pm 0.1$ & $6.8 \pm 0.1$ & $6.5 \pm 0.1$ \\
\hline mNMM-2 & $16.8 \pm 0.2$ & $17.0 \pm 0.3$ & $11.0 \pm 0.1$ & $11.0 \pm 0.1$ & $6.8 \pm 0.1$ & $6.6 \pm 0.1$ \\
\hline
\end{tabular}

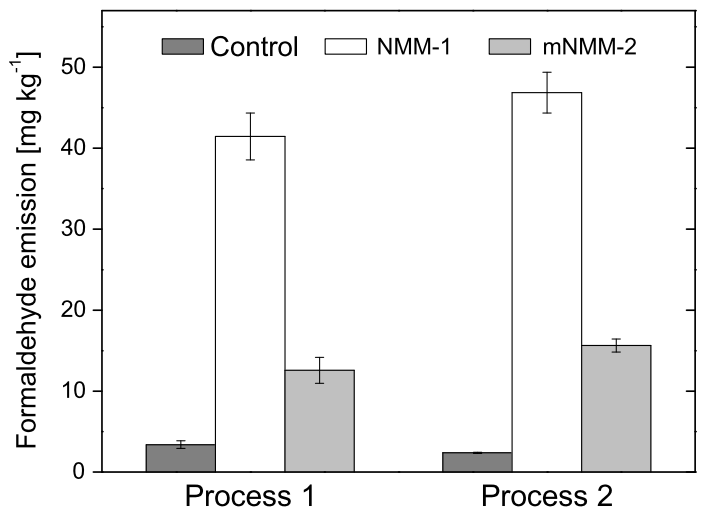

Fig. 6 Formaldehyde emission of the control and treated plywood; statistic comparisons of mean values between process 1 and 2 (Mann-Whitney-U test, $p=0.05$ ) $C_{1}>C_{2} ; M_{1}<M_{2} ; V_{1}<V_{2}$ with $C_{1}, C_{2}$ : Control, process 1 or $2 ; M_{1}, M_{2}$ : NMM-1-treated plywood-process 1 or $2 ; V_{1}, V_{2}:$ mNMM-2 treated plywood-process 1 or $2(n=25$, mean values $\pm \mathrm{SD})$

Abb. 6 Formaldehydabgabe von Kontroll- und behandeltem Sperrholz; statistischer Vergleich der Mittelwerte zwischen Prozess 1 und 2 (Mann-Whitney-U-Test, $p=0,05) C_{1}>C_{2} ; M_{1}<M_{2} ; V_{1}<V_{2}$ mit $C_{1}, C_{2}$ : Kontrolle, Prozess 1 und 2; $M_{1}, M_{2}$ : NMM 1-behandeltes Sperrholz - Prozess 1 oder 2; $V_{1}, V_{2}:$ mNMM-2-behandeltes Sperrholz - Prozess 1 oder $2(n=25$, Mittelwert \pm STD $)$

for the controls); the emission from plywood from the mNMM-2 treated veneers was lower but still 3.7-6.6 times higher than for the controls.

Pre-treated plywood from process 1 displayed statistically significant lower emissions than those produced in process 2 , but still far above the controls. This result for process 1 is attributed to the additional curing time and the rather higher temperature in this pre-curing step of process 1 . High temperature curing leads to a more complete degree of hardening (also most obviously seen as higher degree of cross-linking) of the NMM resins. Hence, a lower content of hydrolysable $N$-methylol groups will remain in the resin. At the high emission due to the NMM treatment (high molar ratio F/M of NMM) compared to the controls without any aminoplastic component, the potential hydrolysis of formaldehyde from the wood substance and hence increase in emission potential might be neglected. This also depends on the question, if formaldehyde created from the wood substance will be vented during the press cycle or if it will remain as gaseous formaldehyde in the board. The influence of the curing temperature and duration on the formaldehyde emission has previously been shown (Lukowsky et al. 1998), where the authors found clearly lower formaldehyde emissions from solid wood treated with 15\% NMM after curing at $120^{\circ} \mathrm{C}$ and $140^{\circ} \mathrm{C}$ compared to the study reported here. In this later case, the shorter curing time during the veneer treatment and the curing in a press (process 1) have obviously restricted the evaporation of formaldehyde from the veneers.

\section{Conclusion}

Plywood produced from beech veneers treated with two NMM compounds at different solid contents exhibited a bonding quality above the requirements of plywood used in non-covered exterior conditions. While the treatment with an aqueous solution of mostly monomeric NMM (NMM-1) tended to increase the bonding strength in both processes applied (hardening of the impregnated resin before or during the press cycle), the treatment with a dispersion of fatty acidmodified $N$-methylol melamine and paraffin (mNMM-2) reduced bond strengths. This was especially the case when curing of the mNMM-2 treated veneers was performed prior to pressing (process 1) as compared to the process of concomitant curing and pressing. Irrespective of the production process, the modification of veneers with both types of NMM compounds causes only minor changes in MOR and $\mathrm{MOE}$ as compared to the control plywood. 
Both $N$-methylol-melamine (NMM) formulations resulted in high water repellence and dimensional stability of beech plywood specimens during a cyclic water submersion and drying procedure; this was especially the case for the mNMM- 2 treatment in process 2 .

The number of delaminated specimens during six cycles was in agreement with the bonding quality rather than with the reduction in water uptake and thickness swelling. The minor reduction of water sorption (EMC) as compared to the control plywood is mainly attributed to a higher mass of the specimens rather than to blocking of the nano-pores in the wood cell wall.

The formaldehyde emission of NMM-1-treated plywood was much higher than that of the controls and the mNMM-2treated specimens; this is a drawback for using NMM-1 treated plywood in service. The so-called E1-limit for formaldehyde emission from plywood determined by the chamber method (EN 717-1 2004) is $0.124 \mathrm{mg} \mathrm{m}^{-3}$ air (EN 636 2003); however there is no E1 threshold for the flask method defined. According to Lukowsky (2002), a formaldehyde value of $3.5 \mathrm{mg} \mathrm{kg}^{-1}$ derived by the flask method corresponds to an emission of $0.1 \mathrm{mg} \mathrm{m}^{-3}$ air determined using the chamber method. This means that the formaldehyde emission from the NMM-1 treated plywood was approximately 10 times above the E1-threshold. The emission can be reduced applying higher temperatures and longer times during the curing of the veneers and the pressing of the boards. In addition, formulations with lower molar ratio formaldehyde: melamine $(\mathrm{F} / \mathrm{M})$ and the addition of formaldehyde scavengers such as urea can reduce the emission. Concomitant curing and pressing in a hot press (process 2) imparts equal or higher performance properties and is also economically favourable as compared to process 1 ; process 1 , however, was more efficient in reducing the formaldehyde emission from the plywood.

Open Access This article is distributed under the terms of the Creative Commons Attribution Noncommercial License which permits any noncommercial use, distribution, and reproduction in any medium, provided the original author(s) and source are credited.

\section{References}

Aarts VM, Scheeoers ML, Brandts PM (1995) Analysis of MF resins. In: Tappi proceedings, European plastic laminates forum, pp 1725

Blank W (1979) Reaction mechanism of melamine resins. J Coat Technol 51:61-70

Borgin K (1965) The testing and evaluation of water repellents. In: Record of fifteenth annual convention-convention of the British Wood Preserving Association, pp 67-84

Christiansen AW (1990) How over-drying wood reduces its bonding to phenol-formaldehyde adhesives: a critical review of the literature, Part I: Physical responses. Wood Fiber Sci 4(22):441-459

Christiansen AW (1991) How over-drying wood reduces its bonding to phenol-formaldehyde adhesives: a critical review of the literature. Part II: Chemical reactions. Wood Fiber Sci 1(23):69-84
Deka M, Saikia CN (2000) Chemical modification of wood with thermosetting resin: effect on dimensional stability and strength property. Bioresour Technol 2(73):179-181

Deka M, Saikia CN, Baruah KK (2000) Treatment of wood with thermosetting resins: effect on dimensional stability strength and termite resistance. Indian J Chem Technol 7(6):312-317

Dieste A, Krause A, Bollmus S, Militz H (2008) Physical and mechanical properties of plywood produced with 1.3-dimethylol4.5-dihydroxyethyleneurea (DMDHEU)-modified veneers of $B e$ tula sp and Fagus sylvatica. Holz Roh- Werkst 66:281-287

Dieste A, Krause A, Bollmus S, Militz H (2009) Gluing ability of plywood produced with DMDHEU-modified veneers of Fagus sp., Betula sp., and Picea sp. Int J Adhes Adhes 29:206-209

Donath S, Militz H, Mai C (2007) Weathering of silane treated wood. Holz Roh- Werkst 65:35-42

Dunky M (2003) Adhesive in the wood industry. In: Pizzi A, Mittal KL (eds) Handbook of adhesive technology, Dekker, New York, pp 887-956

EN 310 (1993) Wood-based panels. Determination of modulus of elasticity in bending and of bending strength. European Committee for Standardisation (CEN), Brussels

EN 314-1 (2004) Plywood-bonding quality-Part 1: Test methods. European Committee for Standardisation (CEN), Brussels

EN 314-2 (1993) Plywood-bonding quality-Part 2: Requirements. European Committee for Standardisation (CEN), Brussels

EN 317 (1993) Particleboards and fibreboards-determination of swelling in thickness after immersion in water. European Committee for Standardisation (CEN), Brussels, Belgium

EN 318 (2002) Wood-based panels-determination of dimensional changes associated with changes in relative humidity. European Committee for Standardisation (CEN), Brussels, Belgium

EN 323 (1993) Wood-based panels. Determination of density. European Committee for Standardisation (CEN), Brussels, Belgium

EN 636 (2003) Plywood-specifications. European Committee for Standardisation (CEN), Brussels, Belgium

EN 717-1 (2004) Wood-based panels-determination of formaldehyde release-Part 1: Formaldehyde emission by the chamber method. European Committee for Standardisation (CEN), Brussels, Belgium

EN 717-3 (1996) Wood-based panels-determination of formaldehyde release-Part 3: Formaldehyde release by the flask method. European Committee for Standardisation (CEN), Brussels, Belgium

EN 1534 (2000). Wood and parquet flooring. Determination of resistance to indentation (Brinell). Test method. European Committee for Standardisation (CEN), Brussels

Gardner DJ, Frazier CE, Christiansen AW (2006) Characteristics of the wood adhesion bonding mechanism using hydroxymethyl resorcinol. In: Proceedings, wood adhesives 2005, San Diego, CA, pp 93-97

Gindl W, Hansmann C, Gierlinger N, Schwanninger M, Hinterstoisser B, Jeronimidis G (2004) Using a water-soluble melamineformaldehyde resin to improve the hardness of Norway spruce wood. J Appl Polym Sci 4(93):900-1907

Hill CAS, Jones D (1996) The dimensional stabilisation of Corsican Pine sapwood by reaction with carbonxylic acid anhydrides. Holzforschung 50:457-462

Hill CAS (2006) Wood modification. Chemical, thermal and other processes. Wiley, New York

Hill T, Lewicki P (2007) Statistics methods and applications. StatSoft, Tulsa

Hunt CG, Bradon R, Ibach RE, Frihart CR (2007) What does bonding to modified wood tell us about adhesion? In: Proceedings 5th COST E34 international workshop, Bled, Slovenia, pp 47-56

Inoue $\mathrm{M}$, Ogata $\mathrm{S}$, Nishikawa M, Otsuka Y, Kawai S, Norimoto M (1993) Dimensional stability, mechanical-properties, and color changes of a low-molecular-weight melamine-formaldehyde resin impregnated wood. Mokuzai Gakkaishi 2(39):181-189 
Kamke F, Lee J (2007) Adhesive penetration in wood-a review. Wood Fiber Sci 2(39):205-220

Kollmann F, Fengel D (1965) Änderungen der chemischen Zusammensetzung von Holz durch thermische Behandlung. Holz RohWerkst 23(12):461-468

Lukowsky D (2002) Influence of the formaldehyde content of waterbased melamine formaldehyde resins on physical properties of Scots pine impregnated therewith. Holz Roh- Werkst 60:349-355

Lukowsky D, Büschelberger F, Schmidt O (1999) In situ testing the influence of melamine resins on the enzymatic activity of basidiomycetes. The International Research Group on Wood Protection, IRG/WP 99-30194, Stockholm, Sweden

Lukowsky D, Peek R-D, Rapp AO (1998) Curing conditions for a low formaldehyde etherificated melamine resin. International Research Group on Wood Protection, IRG/WP 98-40108, Stockholm, Sweden

Nguyen HM (2008) Wood modification with hydrophobation textile finishing agents. Thesis, Georg-August-University, Goettingen, Germany

Nguyen HM, Militz H, Mai C (2007) Protection of wood for above ground application through modification with a fatty acid modified $N$-methylol/paraffin formulation. The International Research Group on Wood Protection, IRG/WP 07-40378, Stockholm, Sweden

Pittman CU, Kim MG, Nicholas DD, Wang LC, Kabir FRA, Schultz TP, Ingram LL (1994) Wood enhancement treatments 1. Impregnation of southern yellow pine with melamine-formaldehyde and melamine-ammeline-formaldehyde resins. J Wood Chem Technol 4(14):577-603

Rapp AO, Peek RD (1996) Melamine resins as preservatives-results of biological testing. The International Research Group on Wood Protection, IRG/WP 96-40061, Stockholm, Sweden

Rapp AO, Peek RD (1999) Melaminharzimprägniertes sowie mit Wetterschutzlasur oberflächenbehandeltes und unbehandeltes Voll- holz während zweijähriger Freilandbewitterung. Holz RohWerkst 57(5):331-339

Roffael E (2006) Volatile organic compounds and formaldehyde in nature, wood and wood based panels. Holz Roh- Werkst 64(2):144149

Rohumaa A, Hughes M, Ohlmeyer M, Kallio T (2007) Raw material and process factors influencing bond strength development in veneer-based products. In: International panel products symposium, Cardiff, Wales, UK, pp 61-69

Rowell RM (1995) Chemical modification of wood for improved adhesion in composites. In: Proceedings, wood adhesives 1995, pp 56-60

Scheepers ML, Gelan RA, Carleer PJ, Adriaensens PJ, Vanderzande DJ (1993) Investigation of melamine-formaldehyde cure by Fourier transform Raman spectroscopy. Vib Spectrosc 6:55-69

Scheikl M, Walinder M (2002) Theory of bonding. In: Dunky M, Pizzi T, Leemput MV (eds) COST Action E13, wood adhesion and glued products. State of the art report, pp 87-95

Son J, Gardner DJ (2004) Dimensional stability measurements of thin wood veneers using the Wilhelmy plate technique. Wood Fiber Sci 36(1):98-106

Talaei A (2008) Material properties of acetylated beech plywood. The International Research Group on Wood Protection, IRG/WP 0840425, Stockholm, Sweden

Trinh HM (2009) Veneer modification for the production of exterior plywood. Thesis, Georg-August-University, Goettingen, Germany

Vick CB, Rowell RM (1990) Adhesive bonding of acetylated wood. Int J Adhes Adhes 10(4):263-272

Xie Y, Hill CAS, Xiao Z, Jalaludin Z, Militz H, Mai C (2010) Water vapor sorption kinetics of wood modified with glutaraldehyde. J Appl Polym Sci 117:1674-1682 